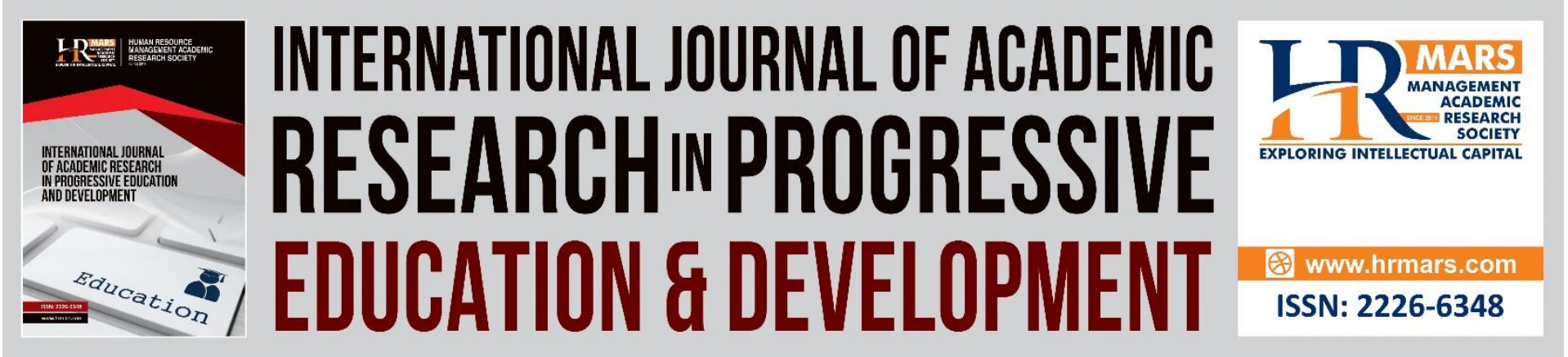

\title{
Interpreting Quran by Quran in Exegetical Manuscripts of of Tihamah Scholars, Yemen
}

Ebrahim Mohammed Abdo AL-ahdal, Mohamed Fathy Mohamed Abdelgelil, Taher Mohammed Abdo AL-ahdal, Mukhamad Hadi Musolin Subagio, Ahmad Fauzi Hassan

To Link this Article: http://dx.doi.org/10.6007/IJARPED/v10-i3/11188

DOI:10.6007/IJARPED/v10-i3/11188

Received: 11 July 2021, Revised: 16 August 2021, Accepted: 30 August 2021

Published Online: 23 September 2021

In-Text Citation: (AL-ahdal et al., 2021)

To Cite this Article: AL-ahdal, E. M. A., Abdelgelil, M. F. M., AL-ahdal, T. M. A., Subagio, M. H. M., \& Hassan, A. F. (2021). Interpreting Quran by Quran in Exegetical Manuscripts of of Tihamah Scholars, Yemen.

International Journal of Academic Research in Progressive Education and Development, 10(3), 775-782.

Copyright: (C) 2021 The Author(s)

Published by Human Resource Management Academic Research Society (www.hrmars.com)

This article is published under the Creative Commons Attribution (CC BY 4.0) license. Anyone may reproduce, distribute, translate and create derivative works of this article (for both commercial and non-commercial purposes), subject to full attribution to the original publication and authors. The full terms of this license may be seen at: http://creativecommons.org/licences/by/4.0/legalcode

Vol. 10(3) 2021, Pg. 775 - 782

http://hrmars.com/index.php/pages/detail/IJARPED

JOURNAL HOMEPAGE

Full Terms \& Conditions of access and use can be found at http://hrmars.com/index.php/pages/detail/publication-ethics 


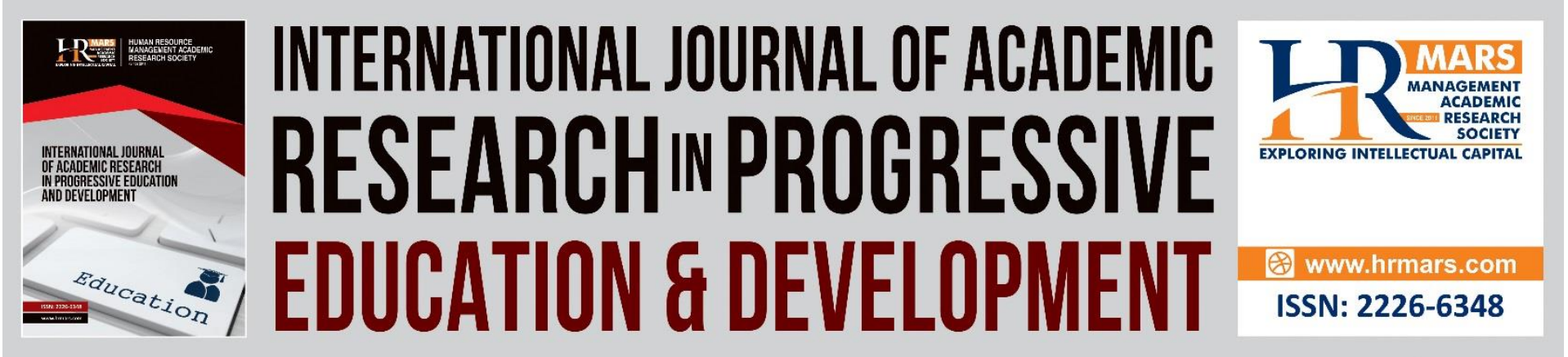

\title{
Interpreting Quran by Quran in Exegetical Manuscripts of of Tihamah Scholars, Yemen
}

\author{
${ }^{1}$ Ebrahim Mohammed Abdo AL-ahdal, ${ }^{1}$ Mohamed Fathy \\ Mohamed Abdelgelil, ${ }^{1}$ Taher Mohammed Abdo AL-ahdal, \\ ${ }^{2}$ Mukhamad Hadi Musolin Subagio, ${ }^{1}$ Ahmad Fauzi Hassan \\ ${ }^{1}$ Faculty of Islamic Contemporary Studies (FKI), Sultan Zainal Abidin University (UniSZA), \\ MALAYSIA, ${ }^{2}$ Sultan Abdul Halim Mu'adzam Shah International Islamic University, \\ (UniSHAMS), Malaysia. \\ Email: mfathy@unisza.edu.my
}

\begin{abstract}
Scholars, in the past and now, have been interested in Mathur exegesis (Tafsir) (interpreting Quran by Quran, by Sunnah or by sayings of the Companions and Tabi'in). One of the most important methods of Mathur exegesis is the exegesis of Quran by Quran. That is where the problem of researching the exegesis of Quran by Quran emerges in the exegetical manuscripts in Tihamah, Yemen, which aims to trace the exegetical manuscripts in Tihamah, Yemen, to find out their method for Mathur exegesis in terms of interpreting Quran by Quran because this is the safest way to understand the Book of Allah Almighty without deviance and distortion. It also aims to build a new list of the scholars of Tihamah, Yemen, to add them to the exegesis scholars in the Islamic world countries, so that students and researchers in the exegetical library can benefit from them. The inductive and descriptive approaches were used by tracing the exegetical manuscripts of the scholars of Tihamah, Yemen, and presenting the methods of Mufasirrin (exegetes) in Tihamah, Yemen, in Mathur exegesis in the practical and objective perspective from their exegesis of Quran by Quran to see the extent of their attention of that by presenting examples from the reality of their exegeses. One of the findings of the research is that interpreting Quran by Quran carries several directions, such as applying the Muqayyad (restricted) on the Mutlaq (unrestricted/absolute) and the Mufassal (explained) on the Mujmal (general/ambiguous), etc., to avoid confusion and etc. It turns out that whoever wants to delve into exegesis should first look at interpreting Quran by Quran, then by Sunnah, then by the sayings of the Companions and Tabi'in. The scholars of Tihamah have a special interest in interpreting Quran by Quran, which deserves attention to direct the attention of researchers to its achievement, printing and publication.
\end{abstract}

Keywords: Exegesis (Tafsir), Manuscripts, Tihamah, Yemen, Quran.

\section{Introduction}

Scholars and researchers have paid great attention to the Holy Quran, its exegesis, and Quranic recitations (readings) (Abdelgelil, 2018; Abdelgelil, 2019) That is because the Holy 
Quran and the ten Quranic recitations are inclusive of everything that is ancient and modern, contemporary and non-contemporary, of family and life affairs (Abdelgelil, 2020), and the insightful observer of the exegesis of the Quranic verses finds that clear; also, the interest in the science of recitations and exegesis, especially interpreting Quran by Quran, has become noticeable in literature and universities and scientific departments (Abdelgelil, 2021).

\section{Linguistic Concept}

The scholars have defined Mathur exegesis as follows: The explanation and clarification of Quranic verses in Quran itself, and what was narrated by the Prophet (PBUH) or by the honorable Companions, or by the Tabi'in, that was authentically conveyed, and it is considered the best and most valid way of exegesis" (Ibn Taimiah, 1980, 93).

In addition, it is the one that should be adopted because it is the path of correct knowledge, and the safest way to understand the Book of Allah Almighty without deviance and distortion" (Al-Kattan, 2000, 350).

\section{The Attention of Scholars Across Yemen to Exegete Quran by Quran}

Many Mufasirrin in Tihamah, Yemen, paid attention to this approach. That is so clear in some exegetical literature that was concerned with this type of exegesis. Here are some applied models and examples transmitted from the reality of their exegeses that clearly indicate the extent of their attention in interpreting Quran by Quran. Some examples are as follows:

\section{Imam Al-Haddad in his Exegesis}

Imam Al-Haddad was distinguished in his exegesis of Quran by Quran. That is clear in applying the Khas (specific) on the A'm (general) in the Almighty's saying: "Divorced women shall wait concerning themselves for three monthly periods" (Quran, Al-Baqara, 2: 228). The general term in the Ayah (verse) is "the divorced" because it is a definite plural term. The surface meaning of the verse is that all divorced women shall wait concerning themselves for three monthly periods; which means that a divorced woman shall wait concerning herself for three monthly periods; however, that is not the intended meaning, as the meaning is specified in other verses. Therefore, we find that Sheik Haddad exegetes this verse as follows: "The divorced woman that is still virgin in this verse is specified in another verse which is the Almighty's saying: "O ye who believe! when ye marry believing women and then divorce them before ye have touched them no period of "Iddah have ye to count in respect of them" (Quran,

Al-Ahzab 27: 49). Likewise, the pregnant woman is specified in another verse. It was narrated that a man from Ashja' said, "O Messenger of Allah, I have divorced my wife while she was pregnant and she has gone. I fear that after she is divorced, she would marry another man, so that my son would be his." Then the Almighty's verse came and said: "Divorced women shall wait concerning themselves for three monthly periods..." (Quran, Al-Baqara, 2: 228). After that, the wife of the man from Ashja' replied him; then, Muath bin Jabal said, "O Messenger of Allah, what about women whose menstrual periods have stopped? How much is their period of 'Iddah? Then, a verse came and said: "Such of your women as have passed the age of monthly courses for them the prescribed period if ye have any doubt is three months" (Quran, At-Talaq, 40: 4). After that, another man said, "what about young girls who have not reached menarche yet?" Then, a verse came and said: "And for those who have no courses". And another man said, "O Messenger of Allah, what about pregnant women? How 
much is their period of "Iddah?" Then the verse came and said: "for those who carry (life within their wombs) their period is until they deliver their burdens" (Quran, At-Talaq, 40: 4). Likewise, the Mujmal is exegeted by the Mubayyan (explained). Shiekh Al-Haddad has mentioned and emphasized that as in his exegesis for the Almighty's saying: "Behold! verily on the friends of Allah there is no fear nor shall they grieve", he says that the meaning is: Except for those whom Allah has entrusted with his protection and guardianship, there is no fear for them on the Day of Resurrection, nor shall they grieve of what they have done in life. Similarly, in the Almighty's saying: "Those who believe and (constantly) guard against evil" (Quran, Yunus, 10: 63), he exegetes it as 'friends of Allah'.

Among Sheikh Al-Haddad's approach in his exegesis is removing confusion in some Quranic verses by other Quranic verses. We can notice him raising question and replying on what the surface meaning includes contradiction; and in such, he is considered follower not creator; as the Companion, Al-Jalil Abdullah bin Abbas, has done so before him. Among what Sheikh has mentioned in his exegesis of the Almighty's saying: "For Allah bestows His abundance without measures on whom He (Quran, Al-Baqara, 2: 212), that if that is said, hasn't Allah said in another verse "Recompense from thy Lord a Gift (amply) sufficient" (Quran, An-Nabaa, 78: 36); therefore, how come He said in this verse ' without measures'?

It is said that Allah's giving is in two types: one is Thawab (rewarding) and the other is bounty. If it is Thawab, then there are measures, for it is measured according to the work. However, if it is bounty, then it is without measurements as the Almighty says: "For He will pay them their meed nay He will give them (even) more out of His Bounty" (Quran, Fatir, 35: 30). And that the meaning intended by the Almighty's saying "recompense" is Thawab not bounty; and that the meaning intended by the Almighty's saying "for Allah bestows His abundance without measures on whom He will" (Quran, Al-Baqara, 2: 212) is bounty (Al-Haddad, 2003, $1 / 86)$.

\section{Imam Al-Hasan bin Aakish in his exegesis Fateh Al-Mannan fi Tafsir Al-Quran}

Aakish has paid great attention in his exegesis of Quran by Quran, whether to clarify the Mujmal, to emphasize the meaning of a verse, to emphasize the meaning of a word or form of I'rab (status of the word in a sentence), or etc., which will be explained later on.

Aakish had his own clear approach in interpreting Quran by Quran through mentioning the meaning of the verse: When interpreting a holy verse, Aakish would be satisfied with referring to the meaning of another verse without stating it; for example, his saying in the exegesis of Muddakir (someone who remember / recall or who is mindful), Al-Qamar, verse (17), and its origin is Mutathakir or Muthtakir (someone who remember) as in Surat Yusuf. And in the Almighty's saying: "The seven heavens and the earth and all beings therein declare His glory: there not a thing but celebrates His praise; and yet ye understand not how they declare His glory! Verily He is Oft- Forbearing Most Forgiving!" (Quran, Al-Israa, 17: 44), what is preponderant has already been explained in the exegesis of Surat Al-Israa" (Aakish, 2003, $1 / 74)$.

\section{Allamah Dhia'a Al-Milah Yusuf bin Mohammed Naser Faqir, Taiseer Marakib Ad-Dukhan bitaiseer Al-Qadir Al-Manan, Exegesis of Surat Ash-Shu'araa}

The Author relied his exegesis on some Quranic verses that refer to the same meaning, as he mentioned that in several places, for example: "It is not ye who slew them; it was Allah: when 
thou threwest (a handful of dust) it was not thy act but Allah's" (Quran, Al-Anfal, 8: 17), "it is He Who hath made the ships subject to you that they may sail through the sea by His command" (Quran, Ibrahim, 14: 32), "it floats under Our eyes (and care)" (Quran, Al-Qamar, 54:14), "in the name of Allah whether it move or be at rest" (Quran, Hud,11:41), "But Allah has created you and your handiwork!" (Quran, As-Saffat, 37: 96) and "(such is) the artistry of Allah Who disposes of all things in perfect order" (Quran, An-Naml, 27: 88); this is a way that informs you of running and steering ships without winds" (Faqir, N. D, 40).

\section{Allamah Mohammed bin Abdulrahman bin Sulaiman Al-Ahdal in his exegesis Removing Doubts and Query in the Exegesis of the Almighty's Saying "But Allah has created you and your handiwork!"}

The Author, in many places of his exegesis, relied on the verses having the same meaning, such as his saying: "such as what has been mentioned on not to make conjunction on a sentence that is like an interrogative sentence such as in the Almighty's saying: "And Abraham prayed for his father's forgiveness ..." (Quran, At-Tauba, 9: 114) after the Almighty's saying: "It is not fitting for the prophet and those who believe" (Quran, At- Tauba, 9: 113), as there is an estimation (and when Abraham prayed for his father's forgiveness), and the replay was made as conjunction after its estimation, and it was replied that 'and' is to resume, not to make a conjunction; and in others. (Al-Ahdal \& Manuscript, 209).

\section{Allamah Abdulkhaliq Ali Al-Mizjaji Miftah Al-Fateh Al-Mubeen min Hadith Bilogh Al- Arba'een wa Ayat Al-Wasiah Bil-Walidain (Miftah Al-Fateh Al-Mubeen of Talk of Reaching Forty Years and Verse of Commandment to Obey Parents)}

The Author, in his exegesis of verse of commandment (Ayat Al-Wasiah), relied on other verses in order to clarify the meaning, such as his saying: "and he reached forty years, which is the end of the strength, beauty, good observing and contemplation of the signs of Allah Almighty for repeated accidents, experiences, and practices for the goodness and bitterness of something, and being kind to parents is the principles of initiation of benevolent slavery, as the Almighty says: "Thy Lord hath decreed that ye worship none but Him and that ye be kind to parents" (Quran, Al-Israa, 17: 23) and the Almighty says: "Show gratitude to Me and to thy parents" (Quran, Luqman, 31: 14); thus, the right of parenting and motherhood is still repeated for him by contemplating the signs of Allah Almighty that are the results of his justifications ... etc. (Al- Mizjaji, Manuscript, 7).

\section{Attention of Iman ibn Nooraddin Al-Muzi'e on Interpreting Quran by Quran}

Allama Al- Muzi'e, in his exegesis, paid great attention to interpreting Quran by Quran. An example of this when interpreting the Almighty's saying: "Write it out for them if you are aware of any good in them" (Quran, An-Nur, 24: 33), he said, "the second judgement, Good, is a common term that is applied on the choice," The Almighty says: "Ye are the best of peoples evolved for mankind" (Quran, Al-i'Imran, 3: 1110), and the Almighty says: "They are the best of creatures" (Quran, Al-Baiyina, 7: 98). The term, Good, also applied on money, the Almighty says: "It is prescribed when death approaches any of you if he leave any goods that he make a bequest" (Quran, Al-Baqara, 2: 180), and the Almighty says: "And violent is he in his love wealth" (Quran, Al-Adiyat, 100: 8). Moreover, it is applied on the success and prosper; the Almighty says: "And do good; that ye may prosper" (Quran, Al-Hajj, 22: 77). And the Almighty says: "Then 
shall anyone who has done an atom's weight of good see it!" (Quran, Al- Zalzalah, 99: 7). In addition, Good is applied on benefit; the Almighty says: "The sacrificial camels we have made for you as among the Symbols from Allah: in them is (much) good for you" (Quran, Al-Hajj, 22: 39), meaning: benefit and reward. The scholars of Quran differed as to what is meant by Good here. Some said that it is righteousness and religion, and their Jumhour (majority) said that it is money"(Al-Muza'l, 2012, 2/ 1007).

\section{Allamah Mohammed Jidi bin Yusuf in his Exegesis Ithaf Fodala'a Al-Asr concerning solving the confusion of the Almighty's saying: "We have indeed revealed this (Message) in the night of Power"}

The Author clarified the meaning of the verse and its exegesis with some verses indicating the same meaning and clarifying it, such as his saying: "... when the great Quran was a name for His old words communicated to His Prophet, who is found between the two bookends, it was everything that it included on it even what he said about Him in it, for it comes under the type and under the name of its name; therefore, communicating it is considered as involving the some into the whole and the evidence of such is the Almighty's saying: "To Praise be to Allah Who hath sent to His Servant the Book and hath allowed therein no Crookedness" (Quran, Al-Kahf 18: 1); thus, all that is in it is from Him, even what He said about Him in it, understand that and beware not to deviate from it so that you will not make a problem(Al-Zabidi, Manuscript, 3).

\section{Allamah Abdullah bin Abdulbari Al-Ahdal Iqadh Al-Hawas Fi Ba'dh Asrar Surat An- Nas (Waking Senses in some Secrets of Surat An-Nas)}

He said, "In Surat Al-Falaq, one of Allah's names, the Lord, is mentioned. In Surat An-Nas, three names are mentioned. The case is that in Surat Al-Falaq, the thing that refugee is sought from is more than one, and in Surat An-Nas, it is one; what is the wit in that? Al-Fakhr Al-Razi said in his exegesis that one should know that there is a great goodness in this Surah, which is as follows: The refuge sought with in the first Surah, Al-Falaq, is mentioned in one description which is the Lord of the Dawn, and the refuge sought from is mentioned in three mischiefs: Mischief of Darkness, Mischief of those who Practice Secret Arts, and Mischief of the Envious; however, in this Surah, An-Nas, the refuge sought with is mentioned in three descriptions: the Lord, the King and Allah, and the refuge sought from is mentioned in one mischief, Whisperer (of Evil). The difference between the two is that praise should be measured by the required; what is required in the first Surah is the integrity of the soul and body, and what is required in the second Surah is the integrity of religion. That is a warning that harming religion, even a little, is greater than harming the world, even a lot, full stop. I said that it is answered that the evils attributed to someone other than the devil, when they come from one side and their harmfulness do not end except for the soul and the body, seeking refuge from them comes in the description of the Lord; that is because holding physical and psychological harm is education; and when the devil comes from the four sides as Allah Almighty said about him: "I (the devil) will assault them from before them and behind them from their right and their left". Its harm for the body, soul, and religion ends by seeking refuge from it; therefore, three descriptions, that include the meanings of all Allah's names, were given. That is because the description of the Lord indicates education, because seeking refuge from his evil that harms the body and soul is education. Furthermore, the description of the King indicates the realization of ownership over the slave by holding the evil of 
possessing him by Satan, so he is not truly possessed except by the Almighty, for whoever is possessed by Satan as if he were his servant and as if Satan is his king. Moreover, description of Allah indicates achieving the servitude of slave and deification of Allah Almighty; as whoever obeys Satan and follows his own whims becomes as if Satan is his god. "Of those who reject faith the patrons are the Evil Ones", Allah conferred on me this meaning and I ask Allah Almighty that it is not countered; therefore, seeking His refuge or asking for it shall be only in the name of the self, which is Allah, or what gives its meaning, such as the Almighty's sayings: "Allah save me from being an ignorant (fool)!", "I seek Thy protection for her", because the pronoun belongs to Him Almighty, and "O my Lord! I do seek refuge with Thee" (Al-Ahdal, 1983, 14).

\section{Conclusion}

This research ends with a conclusion. It reaches the following findings:

1. The scholars of Tihamah have paid a special attention to Mathur exegesis, for it is the safest way to understand and exegete Quran.

2. Interpreting Quran by Quran has many directions such as applying Al-Muqayyad on Al-Mutlaq, Al-Mufassal on Al-Mujmal and Al-Khas on Al-A'm, as well as avoiding confusion and etc.

3. It turn out that whoever wants to delve into exegesis should first look at interpreting Quran by Quran, then by Sunnah, then by the sayings of the Companions and Tabi'in. Also, it is recommended to inquire on Mufasirrin from the scholars of Tihamah to exegete the Quranic verses through Mathur exegesis according to Quran, then Sunnah, then the sayings of the Companions and Tabi'in, and study it objectively.

\section{Acknowledgement}

Special thanks go to the Research Management, Innovation and Commercialization Centre (CREIM), Sultan Zainal Abidin University (UniSZA), MALAYSIA.

\section{References}

Al-Quran Al-Karim.

Abbas, F. (1997). Itqan al-Burhan Fi Ulum al-Qur'an, Amman: Dar al-Furqan.

Abdelgelil, M. F. M. (2020). Grammarians' Critique of Qur'anic Qira'at. International Journal of Academic Research in Business and Social Sciences, 10(11), 1225-1231.

Abdelgelil, M. F. M. (2020). Solving the Quranic Issues with Quranic Qira'at, International Journal of Academic Research in Business and Social Sciences, 10(12), 36-42.

Abdelgelil, M. F. M., Al-Janayni, M. U., Baru, R., Hamzah, M. S., Razali, M. A. T. M., \& Ismail, F. Z. (2018). Tawjih Al-Qira'at Based on Inscription, Language, and Unusual Modes of Recitation According to Ibn Zanjalah. International Journal of Academic Research in Business and Social Sciences, 8(10), 362-370.

Abdelgelil, M. F. M., Daud, N. B., Omar, N. B., Ismail, F. Z. B., \& Wahab, A. H. B. A. (2018). Taujeeh Al-Qira'at Using Qur'an, Hadith and Poetry according to Ibn Zanjalah. International Journal of Academic Research in Business and Social Sciences, 8(10), 371379.

Abdelgelil, M. F. M., Hasan, A. F., Yusoh, F, El khayat, M. H. M., Razali, M. A., Ismail, F. Z., \& Ab Rashid, R. (2021). Correlation Between Irregular Qiraat And Arabic Linguistics In The 
Quranic Tafseer Book By Al-Razi. International Journal of Academic Research in Business and Social Sciences, 11(7), 1632-1639.

Abdelgelil, M. F. M., Hasan, A. F., Yusoh, F., Ismail, F. Z., Ab Rashid, R., Ab Aziz, N. S., Hassan, A (2021). The Impact of Irregular Qiraat on Arabic Semantics and Dialects. International Journal of Academic Research in Business and Social Sciences, 11(7), 1672-1676.

Abdelgelil, M. F. M., Hasan. A. F., Yusoh, F., El khayat, M. H. M., Razali, M. A., Hassan, A., Ab Aziz, N. S. (2021). Arabic Syntactic Rules with Reference to Quranic Qurra. International Journal of Academic Research in Business and Social Sciences, 11(7), 1707-1711.

Abdelgelil, M. F. M., Musolin, M. H., Serour, R. O. H., Abdullah, M. S., \& Noor, M. N. M. (2018). Law and Moral Values in the Holy Quran. International Journal of Academic Research in Business and Social Sciences, 8(11), 445-451.

Abdelgelil, M. F. M., Osman, M. F. M. A., Serour, R. O. H., Subagio, M. H. M., Othman, A. K. I., \& Hassan, A. F. (2021). The History of the Qur'anic Enigma and the Impact of Interpretation in Directing it. International Journal of Academic Research in Progressive Education and Development, 10(3), 412-418.

Abdelgelil, M. F. M., Othman, A. K. I., Serour, R. O. H., Osman, M. F. M. A., \& Hassan, A. F. (2021). Ibn Qutayba's Response to the Slanderers who Claim Grammatical Mistake in the Qur'an. International Journal of Academic Research in Progressive Education and Development, 10(3), 419-426.

Abdelgelil, M. F. M., Othman, A. K. I., Subagio, M. H. M., Serour, R. O. H., Hassan, A. F., \& Osman, M. F. M. A. (2021). Directing the Enigma of Quranic Words According to lbn Qutaybah and Al-Far. International Journal of Academic Research in Progressive Education and Development, 10(3), 427-434.

Abdelgelil, M. F. M., Razali, M. A., Hassan, A., Hasan, A. F., Idris, M. F. H., \& Masoud. (2020). A.S,Quranic Inimitability in Quranic Qiraat, International Journal of Management, 11(10), pp. 117-121.

Al- Mizjaji, A. A., (Manuscript). Miftah Al-Fath Al-Mubin.

Al-Ahdal, A. (1983). leqaz Al-Hawas. Makkah: Al-Nahdhah Al-Hadisah.

Al-Ahdal, M. A. S. (Manuscript). Daf' Al-Shukuk Wa Al-Zunun.

Al-Haddad, A. A. (2003). Tafsir Al-Haddad Kashf Altanzil Fi Tahkik Al-Mabahis Wa Al-Ta'wil. Bairut: Dar Al-Madar Al-Islami.

Al-Kattan, M. K. (2000). Mabahith Fi Ulum Al-Quraan. Bairut: Maktabah Al-Ma'arif.

Al-Muza'i, M. A. (2012). Al-Bayan Fi Ahkam Al-Quran. Investigation: Abdul Mun'im. Dimashq: Dar Al-Nawadir.

Al-Zabidi, M. (Manuscript). Ithaf Fudhala' Al-Asr.

Faqir, Y. M. N. (N. D). Taisir Marakib Al-Dukhan Bi Taisir Al-Qadir Al Manan Tafsir Ayat AlShura. Manuscript.

Ibn Taimiah, A. A. (1980). Muqaddimah Fi Usul Al-Tafsir. Bairut: Dar Maktabah Al-Hayah. 